\title{
Review on the Effect of Irrigation Interval on Different Crop Production
}

\author{
Dessie Gieta Amare \\ Department of Natural Resources Management, Debre Markos University, Ethiopia; P.O Box: 18
}

\begin{abstract}
In these review I have been review the effect of irrigation intervals on growth and yield of onion, effect of irrigation intervals to optimize maize yield, effect of irrigation interval on growth characteristics for Chile pepper, effect of irrigation interval on vegetative growth and yield, effects of irrigation interval on growth analysis of soybean, effect of irrigation intervals on forage production, effect of irrigation interval on growth and development of tomato, effect of irrigation level and irrigation frequency on the growth of mini Chinese cabbage and Influence of irrigation interval, nitrogen level and crop geometry on production lettuce. The best performance irrigation interval for maize, pepper, okra, soybean, forage, tomato, cabbage and lettuce are 5, 6, 1, $12,8,20,1,4$ and 2 day respectively. Crop type, crop growth stage soil type, climate condition (temperature, rainfall, humidity, sunshine hour and wend speed) duration of the environment should be properly addressed and potential evapotranspiration and reference evapotranspiration should be estimated for determine of irrigating interval. In in these case some of the studies are properly addressed these important parameters but some of the study not indicates. On the other hand chemical composition of water and soil, fertilizer application, method of research design and plant geometry are should be identify to eradicate the misjudgment of your best productivity of irrigation interval.
\end{abstract}

Keywords: interval, yield, irrigation, growth, crop

DOI: $10.7176 / \mathrm{JNSR} / 12-4-04$

Publication date: February $28^{\text {th }} 2021$

\section{INTRODUCTION}

In the real world, the quantity of rainfall, duration and distribution of rain fall are mostly irregular in some period may a shortage of rainfall and on the other hand some periods show excess rainfall occurred ; the use of irrigation technology eradicate rainfall dependent crop production and would significantly improve and raise the level of production (Haile, 2014). The crop water requirement and the timing of irrigation are governed by prevailing climatic conditions ( sun shine duration, temperature, humidity, wind speed and rainfall), crop type (different crop type have different water need in the same climate condition) and stage of growth (late season, development stage, midseason stage and initial stage), type of soil also determine timing of irrigation (soil moisture holding capacity) and the extent of root development as determined by crop type, stage of growth and soil. Thus, the quantity of water required by crop varies from place to place or crop to crop. Crop yield is affected by different factors other than water such as crop variety, soil salinity, pests, diseases and agronomic practices. Also, improved water management would help in coping with increasing demands for water by industrial and urban users and the agricultural sector (De Fraiture and Wichelns, 2010). How much water apply and when irrigation water apply is a critical irrigation water management input to ensure optimum soil moisture status for proper plant growth and development as well as for optimum yield, water use efficiency and economic benefits. Therefore, it is essential to develop irrigation scheduling strategies under local climatic conditions to utilize scarce water resources efficiently and effectively (De Fraiture et al., 2010).

\section{Objectives}

To review factors for crop production beside of irrigating interval on the yield and quality

To review effect of irrigation interval with the aim of minimizing water consumption on growth and yield of the crop

To review the comparative effect of irrigation interval among different crop type

\section{LITERATURE}

\subsection{Effect of Irrigation Intervals on Growth and Yield of Onion}

These review focused on the evaluation of the effect of different irrigation intervals on different onion varieties a research was conducted in the Research Area, Arid Agriculture, Rawalpindi, during 2001 - 2002. The researcher conducted experiment for the evaluation of two onion varieties, namely, "Swat-1" and "Phulkara" for their productivity by different irrigation interval. The cultivated soil layer $(0-80 \mathrm{~cm})$ in the experimental area is heavy soil (55\% sand, $32 \%$ silt, and 13\%clay). By considering different irrigation interval treatments consist of control irrigation after 5 days irrigation interval, 10 days irrigation interval, 15 days irrigation interval and 20 days irrigation intervals. The research results indicated that the maximum seedling survival percentage $98 \%$ and $97 \%$ 
was observed in plots with 5 days of irrigation interval in Swat I and Phulkara onion varieties, respectively. The investigator was observed that the maximum Number of leaves plant ${ }^{-1}$, plant height and sprouting after harvest was significantly different in 5 days of irrigation intervals than other treatments both in Swat-1 and Phulkara varieties i.e., 10 days irrigation interval, 15 days irrigation interval and 20 days irrigation intervals. Concerning to the reproductive parameters both varieties showed better outcome in 5 days of irrigation intervals than other treatments. The investigator was concluded that 5 days of irrigation interval is a better productive as compared to other treatments (irrigation interval) in case of plant bulb yield and growth. Whereas, Swat-1 onion varieties were performed better for plant growth and bulb yield parameters as compared to Phulkara onion varieties under the climatic conditions of Rawalpindi. Furthermore the investigation indicated that more benefit of cost ratio was obtained in case of Swat-1 onion varieties as compared to Phulkara onion varieties. The graph shown below indicates the comparison of two onion varieties in different parameters in different irrigation interval (Mateen ul Hassan Khan et al, 2005).
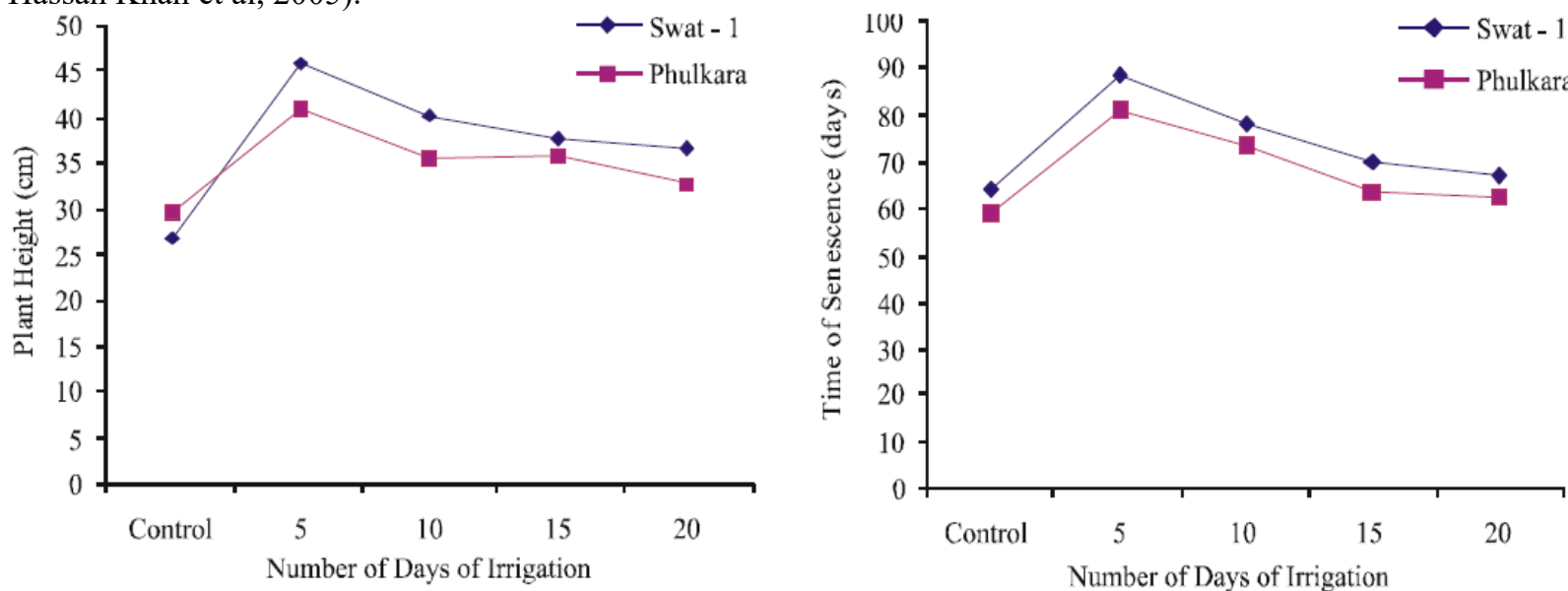

Figure: 2.1. a and b. Effect of irrigation interval on plant height $(\mathrm{cm})$ and senescence (day) of two onion varieties (Mateen ul Hassan Khan et al, 2005).
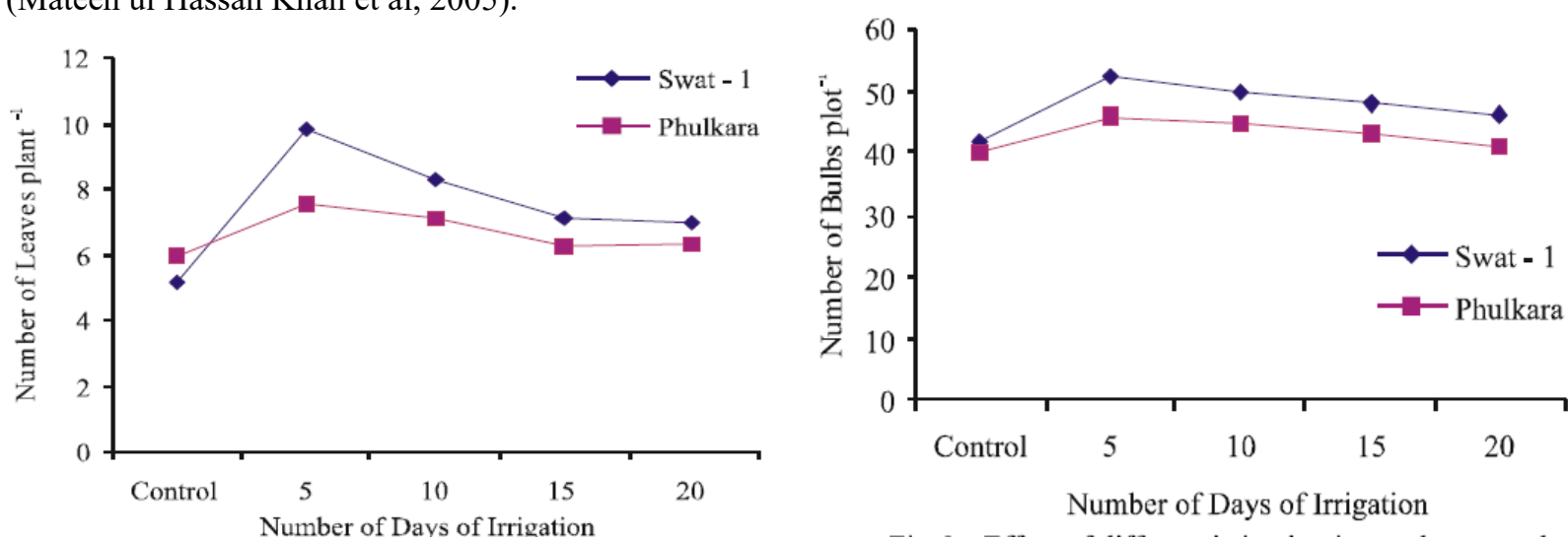

Figure: 2.2. $\mathrm{c}$ and d. Effect of irrigation interval on number of leaves per plant $(\mathrm{cm})$ and total number of bulb per plant of two onion varieties (Mateen ul Hassan Khan et al, 2005).
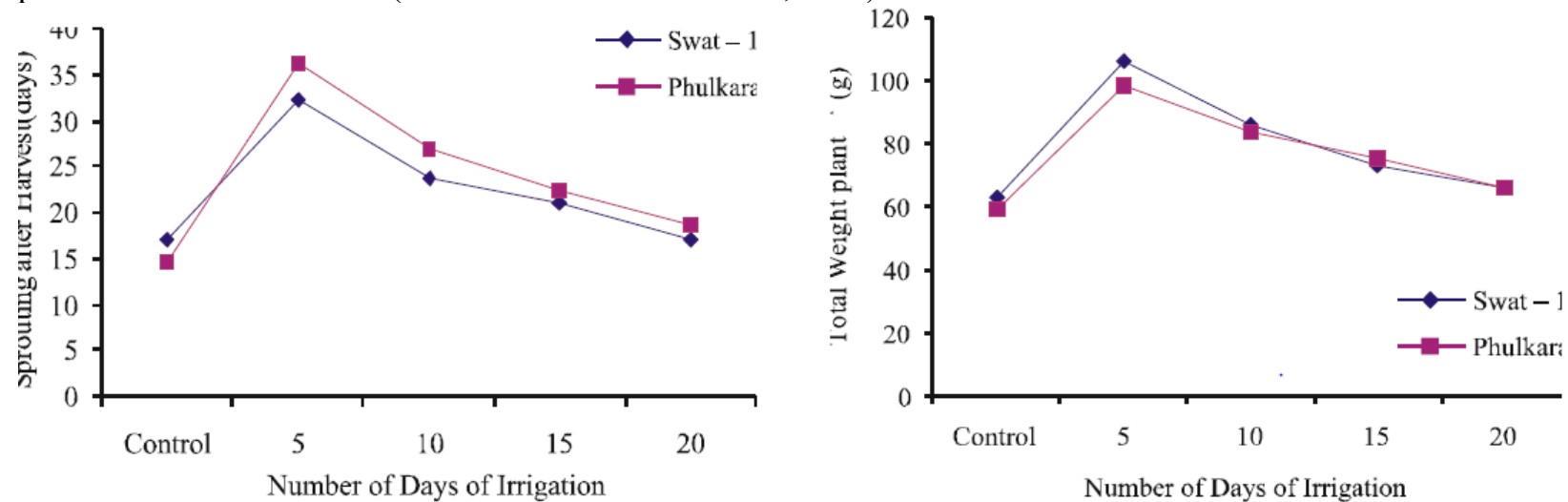

Figure: 2.3. e and f.Effect of irrigation interval on sprouting after harvest (day) and total weight per plant of two onion varieties (Mateen ul Hassan Khan et al, 2005). 

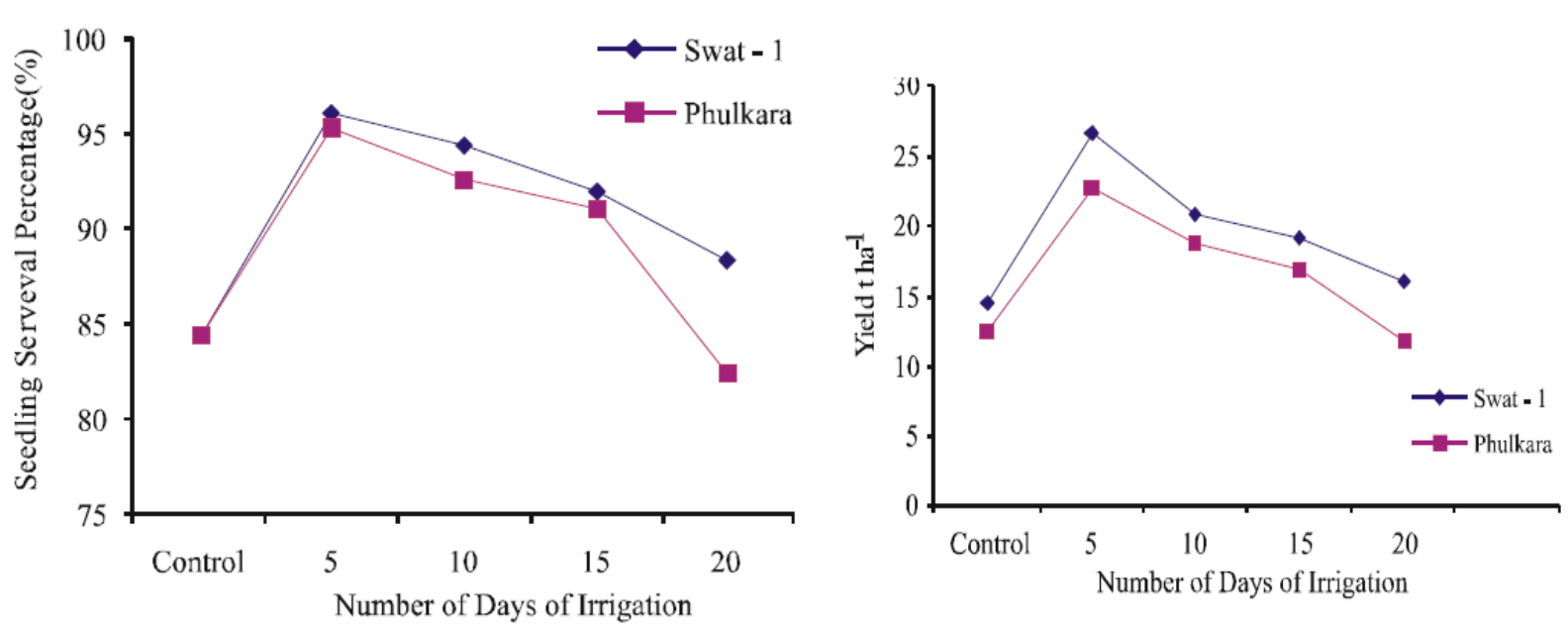

Figure: 2.4. $\mathrm{g}$ and effect of irrigation interval on seedling survival percentage (\%) and yield (tha ${ }^{-1}$ ) of two onion varieties(Mateen ul Hassan Khan et al, 2005).

\subsection{Effect of irrigation intervals to optimize maize yield}

To review this study I have seen that the investigator conduct these study to identify the effect of irrigation intervals to optimize maize yield by considering water use efficiency of the irrigation. The study applies under drip irrigation method. These physical and chemical properties of the soil were measured at the beginning of each field experiment. The experimental field soil type is sandy loam. The climate in this region is characterized by minimal rainfall and many hours of sunshine. The mean precipitation was $158.6 \mathrm{~mm}$, the mean daily temperature was $18.8^{\circ} \mathrm{C}$, the mean reference crop evapotranspiration was $1386.0 \mathrm{~mm}$, and the mean total annual hours of sunshine was $1693.3 \mathrm{~h}$. The precipitation was $208.2 \mathrm{~mm}$ (2016) and $166.0 \mathrm{~mm}$ (2017) during the growth period of maize. This study conducted whether irrigation frequency can be used to adjust soil moisture to increase grain yield and water use efficiency (WUE) of high-yield maize under conditions of mulching and drip irrigation. A field experiment was done using 3 irrigation schedule in 2016: 6, 9, and 12 days irrigation intervals (labeled $\mathrm{D}_{6}, \mathrm{D}_{9}$, and $\left.\mathrm{D}_{12}\right)$ and 5 irrigation schedule in 2017: $3,6,9,12$, and 15 days irrigation intervals $\left(\mathrm{D}_{3}, \mathrm{D}_{6}\right.$, $\mathrm{D}_{9}, \mathrm{D}_{12}$, and $\mathrm{D}_{15}$ ). In the research area, an optimal irrigation depth (amount of water applied) was $540 \mathrm{~mm}$ for high-yield maize production. The 5 irrigation schedule in $2017: 3,6,9,12$, and 15 days irrigation intervals $\left(\mathrm{D}_{3}\right.$, $\mathrm{D}_{6}, \mathrm{D}_{9}, \mathrm{D}_{12}$, and $\mathrm{D}_{15}$ ) irrigation intervals gave grain yields of $19.7,19.1-21.0,18.8-20.0,18.2-19.2$, and $17.2 \mathrm{Mg}$ $\mathrm{ha}^{-1}$ and a water use efficiency ( WUE) of $2.48,2.53-2.80,2.47-2.63,2.34-2.45$, and $2.08 \mathrm{~kg} \mathrm{~m}^{-3}$, respectively. Treatment $\mathrm{D}_{6}$ (3 day irrigation interval) lead to the highest soil moisture storage, but evapotranspiration and soilwater evaporation were lower than other treatments. These investigation results indicated that irrigation interval $\mathrm{D}_{6}$ can help maintain a favorable soil-moisture environment in the upper-60-cm soil layer, reduce soil water evaporation and evapotranspiration, and produce the highest yield and WUE. In this arid region and in other regions with similar soil and climate conditions, a similar irrigation interval would thus be beneficial for adjusting soil moisture to increase maize yield and WUE under conditions of mulching and drip irrigation (Guoqiang Zhang et al, 2019).

Table: 2.2. Gain yield for different irrigation interval (four treatments) (Guoqiang Zhang et al, 2019).

\begin{tabular}{|c|c|c|c|c|}
\hline Year & Cultivar & Irrigation interval & Grain yield (Mgha ${ }^{-1}$ & WUS $\left(\mathrm{kgm}^{-3}\right)$ \\
\hline \multirow{6}{*}{2016} & ZD958 & D6 & $19.1 \mathrm{a}$ & $2.53 \mathrm{a}$ \\
\hline & & D9 & $18.8 \mathrm{~b}$ & $2.47 \mathrm{~b}$ \\
\hline & & D12 & $18.2 \mathrm{c}$ & $2.34 \mathrm{c}$ \\
\hline & & D6 & $20.6 \mathrm{a}$ & $2.71 \mathrm{a}$ \\
\hline & XY335 & D9 & $19.8 \mathrm{~b}$ & $2.58 \mathrm{~b}$ \\
\hline & & D12 & $18.7 \mathrm{c}$ & $2.41 \mathrm{c}$ \\
\hline \multirow{5}{*}{2017} & XY335 & D3 & $19.7 \mathrm{~b}$ & $2.48 \mathrm{c}$ \\
\hline & & D6 & $21.0 \mathrm{a}$ & $2.80 \mathrm{a}$ \\
\hline & & D9 & $20.0 \mathrm{~b}$ & $2.63 \mathrm{~b}$ \\
\hline & & D12 & $19.2 \mathrm{c}$ & $2.45 \mathrm{c}$ \\
\hline & & D15 & $17.2 \mathrm{~d}$ & $2.08 \mathrm{~d}$ \\
\hline
\end{tabular}

\subsection{Effect of Irrigation Interval on Growth Characteristics for Chile Pepper}

Effects of Irrigation Interval on Growth Characteristics for Chile Pepper have been reviewed in this paper. In these investigation a container experiments were conducted to investigate the effect of irrigation interval on root 
development, yield and water use efficiency for Chile pepper production. Each experiment container has a size of $31 \mathrm{~cm} \times 15 \mathrm{~cm} \times 60 \mathrm{~cm}$ with one transparent side for the purpose of visual view of the root development in the container. The researcher use sandy clay loam for the crop grown. The soil (sandy clay loam soil) was filled in each container to a $50 \mathrm{~cm}$ height. One seedling of Chile pepper (Takano tsu me) was transplanted in the middle of each container on the 15th of February, 2005. The treatment done in the three irrigation intervals (1, 3 and 5 day) with four replications were investigated. The soil moisture in each experiment container was kept at field capacity by compensating the loss in weight by adding water. The investigation result indicated that increasing the water supply caused increases in the root biomass. The 1-day irrigation interval produced the highest root biomass while the 5- day resulted in the least root biomass. The 3-day irrigation interval showed remarkable roots development in the bottom of the containers, resulting in $12 \%$ water saving compared to other treatments. The increasing in the irrigation interval induced an increase in the xylem water potential but it caused a reduction in leaf growth. Generally, the proper irrigation interval increases the plant water stress tolerance by developing the root in lower layers where high soil moisture content is present (Saleh M. Ismail and Kiyoshi Ozawa, 2009).

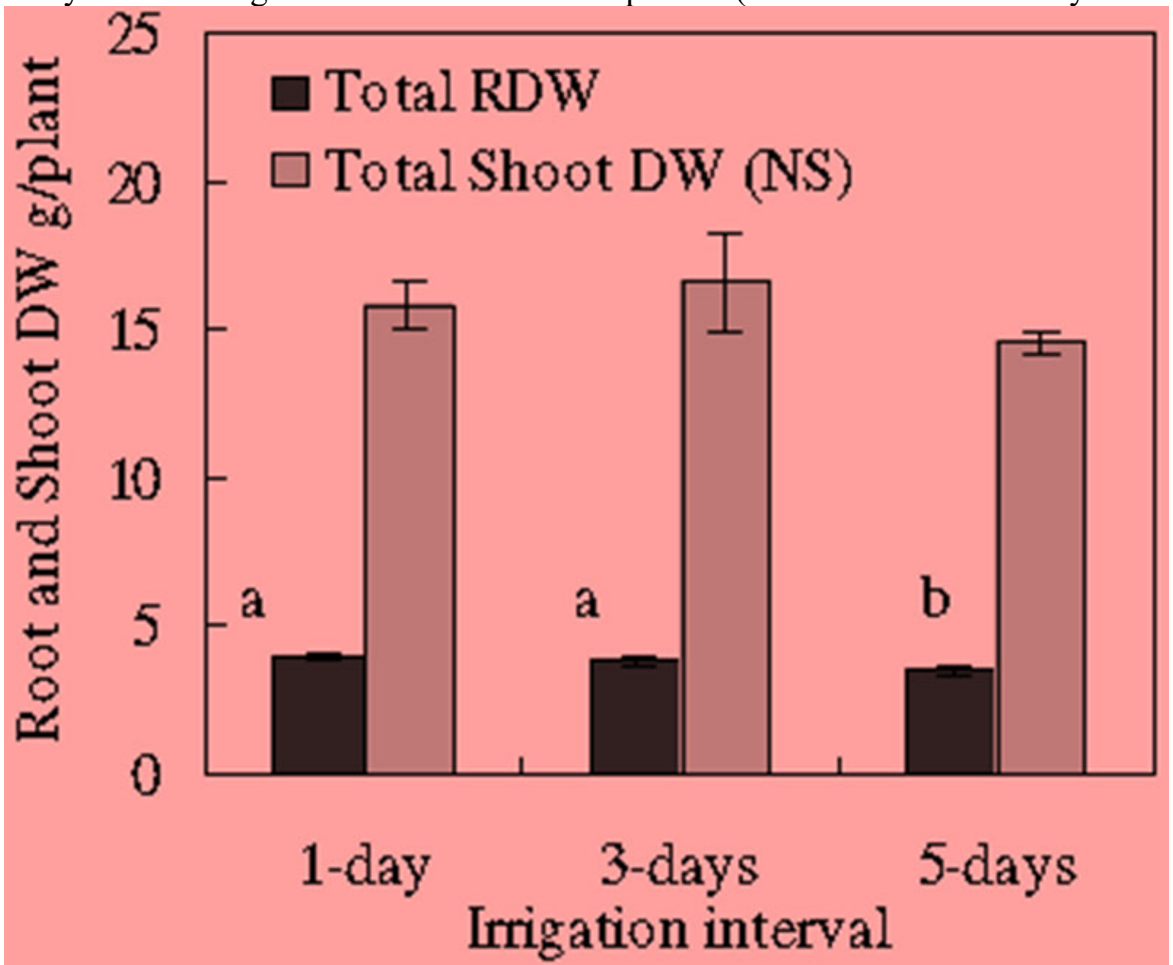

Figure: 2.3. Effect of irrigation interval on root and shoot dry weights (Saleh M. Ismail and Kiyoshi Ozawa, 2009).

\subsection{Effect of Irrigation Interval on Vegetative Growth and Yield}

Many studies indicated irrigation interval affect the production of the crop productivity. In these review also the effect of Irrigation Interval on Vegetative Growth and Yield have been reviewed. The investigator doing this work was conducted at the Experimental Farm, Fac. Agric, Assiut University, Assuit. Tow genotypes of okra i.e., line 16 and the locally adapted type "Balady" was subjected to different irrigation interval i.e., 12, 18, 24 and 30 days. Planting was arranged on ridges $80 \mathrm{~cm}$ apart with $30 \mathrm{~cm}$ spacing between plants with furrow irrigation method and applying the recommended quantity of irrigation water. The results of investigation indicated that plants of line 16 documented higher values regarding plants height dry matter \% in of each vegetative and root parts, fruit length and yield under all of the tasted irrigation intervals. However, the Balady genotype was superior to line 16 in respect of fruit weight and root length. Irrigation interval showed pronounced effect on most of the studied character. For example watering every 12 days gave the highest yield, greater number of roots, while prolonging irrigation up to 24 of the 30 days revealed the earliest flowering time (days) and it also led to closure of stomata in line 16. The most pronounced effect for the interaction was that fund between line 16 when irrigated at 12 days intervals where the highest fruit yield and greatest number of roots were recorded in both seasons of study. The Average plant stems length $(\mathrm{cm})$ in two okra caltivars ("Balady" and "line 16") as affected by irrigation interval under different season were shown in the table $2.4 \mathrm{a}$. and average root length (cm) and number of branch/root in two 0rka cultivars as affected by irrigation interval during 2007 and 2008 seasons shown in table 2.4b, respectively (Hassan A.Hussein et al, 2011). 
Table: 2.4a. Average plant stems length (cm) in two okra caltivars ("Balady" and "line 16") as affected by irrigation interval under different season (Hassan A.Hussein et al., 2011).

\begin{tabular}{ccccccc}
\hline $\begin{array}{c}\text { Irrigation interval } \\
\text { (day) }\end{array}$ & \multicolumn{3}{c}{$\mathbf{2 0 0 7}$} & \multicolumn{3}{c}{$\mathbf{2 0 0 8}$} \\
\cline { 2 - 7 } $\mathbf{1 2}$ & Balady & Line16 & Mean & Balady & Line16 & Mean \\
$\mathbf{1 8}$ & 142.00 & 17.22 & 159.11 & 138.48 & 186.67 & 162.58 \\
$\mathbf{2 4}$ & 135.33 & 167.22 & 151.28 & 135.05 & 177.22 & 156.14 \\
$\mathbf{3 0}$ & 116.00 & 140.22 & 128.11 & 125.33 & 138.89 & 132.11 \\
Mean & 103.89 & 112.33 & 108.11 & 112.83 & 115.44 & 109.14 \\
\hline
\end{tabular}

Table: $2.4 \mathrm{~b}$. Average root length $(\mathrm{cm})$ and number of branch/root in two 0rka cultivars as affected by irrigation interval during 2007 and 2008 seasons (Hassan A.Hussein et al., 2011).

\begin{tabular}{|lllllll|}
\hline $\begin{array}{l}\text { Number of branch } \\
\text { Mean }\end{array}$ & Line 16 & Balady & Mean & Line 16 & Balady & $\begin{array}{l}\text { Irrigation } \\
\text { interval (day }\end{array}$ \\
\hline $\mathbf{2 0 0 7}$ & & & 2007 & & & \\
\hline $\mathbf{1 8 . 3 4}$ & 17.67 & 19 & 44.6 & 44.00 & 45.22 & 12 \\
\hline $\mathbf{1 3 . 0 0}$ & 12.22 & 13.78 & 39.22 & 37.00 & 41.44 & 18 \\
\hline $\mathbf{9 . 8 9}$ & 9.56 & 10.22 & 34.95 & 32.22 & 37.67 & 24 \\
\hline $\mathbf{6 . 9 5}$ & 6.89 & 7 & 27.28 & 26.22 & 28.33 & 30 \\
\hline & 11.59 & 12.5 & & 34.22 & 38.17 & Mean \\
\hline $\mathbf{2 0 0 8}$ & & & 2008 & & & \\
\hline $\mathbf{2 4 . 5}$ & 24.56 & 24.44 & 40.28 & 37.33 & 43.22 & 12 \\
\hline $\mathbf{1 6 . 6 7}$ & 16.00 & 17.33 & 32.17 & 30.22 & 34.11 & 18 \\
\hline $\mathbf{1 1 . 7 3}$ & 11.78 & 11.67 & 28.11 & 26.78 & 29.44 & 24 \\
\hline $\mathbf{8 . 4 5}$ & 8.67 & 8.22 & 22.11 & 22.22 & 22.00 & 30 \\
\hline & 15.25 & 15.42 & & 29.14 & 32.19 & Mean \\
\hline
\end{tabular}

\subsection{Effects of Irrigation Interval on Growth Analysis of Soybean}

The productivity soybean crop also affected by the amount of water applied and the interval of irrigation (how much and when apply water to the crop). In these review effects of Irrigation interval on growth analysis of soybean was addressed. Furrow irrigation method was done for all irrigation intervals and maximum and minimum daily temperature was $27 \& 13^{\circ} \mathrm{C}$, respectively

The researcher in these paper have been a conducted field experiment with the ultimate goal of irrigation is to utilize added water efficiently on soybean that can give the greatest seed yield per hectare increase from added water in crop year 2015/2016 BC at Hawassa. An investigator during investigation experiment was done using Random complete block design (RCB) with four replication was applied on the field. During investigation each experimental design unit with size of $2 \times 2 \mathrm{~m}$ and was planted with 5 rows. The experimental (test) irrigation interval was 3,8,13 days. Then the researcher tests these three irrigation schedules $(3,8,13$ days irrigation interval) on the field to see the effect of irrigation interval on plant morphological characteristics and its productivity. The researcher collect data from filed experiment such as stem weight, leaf weight, leaf area, plant weight and plant height. After collecting field experimental data such as stem weight, leaf weight, leaf area, plant weight and plant height. NAR and RGR were analyzed. The maximum RGR and NAR were recorded at 8 day irrigation interval with a value of $102.5 \mathrm{mg} \mathrm{g}^{-1}$ day $^{-1}$ and $77.5 \mathrm{mgg}^{-1} \mathrm{day}^{-1}$ respectively. The highest biomass of soybean crop was recorded at irrigation intervals of 3 days with a mean value $176.7163 \mathrm{gm}^{-2} \mathrm{v}$. Mean total relative growth rate, assimilation rate and dry weight for soybean under different irrigation interval were indicted in the table 2.5. (Lake Mekonnen, 2018).

Table: 2.5. Mean total relative growth rate, assimilation rate and dry weight for soybean under different irrigation interval (Lake Mekonnen, 2018).

\begin{tabular}{|c|c|c|c|}
\hline & RGR(mgg ${ }^{-1}$ day $\left.^{-1}\right)$ & NAR(mgg ${ }^{-1}$ day $\left.^{-1}\right)$ & Biomass $\left(\mathrm{gm}^{-2}\right)$ \\
\hline Irrigation interval (day) & Mean $\pm \mathrm{SE}$ & mann $\pm S F$ & MRAMI士SP \\
\hline 3 & $83.75 \pm 5.57$ & $63.5 \pm 5.57$ & $176.72 \pm 19.04$ \\
\hline 8 & $102.5 \pm 5.57$ & $77.5 \pm 5.57$ & $81.39 \pm 19.04$ \\
\hline 13 & $94.25 \pm 5.57$ & $70.75 \pm 5.57$ & $89.6 .9 \pm 19.04$ \\
\hline
\end{tabular}

RGR $=$ Relative Growth Rate and NAR = Net Assimilation Rate 


\subsection{Effect of Irrigation Intervals on forage production}

In this section of review focused on effect of irrigation intervals on forage production specially Alfalfa (Medicago sativa L) based on the study. Alfalfa (Medicago sativa L) is a common and most important forage crop throughout the worldwide for cattle feed, its quantity of the yield and quality of the yield can be most determent factor for forage production. This important factor can be improved by better irrigation water management and using improved varieties of forage. The climate condition of the research area was classified into the sub-tropical zone with the mean temperature $\left(17.41 \mathrm{c}^{\circ}\right)$, mean humidity $(60.66 \%)$ and mean rainfall $(6.36 \mathrm{~mm})$ during the research period. The soil $\mathrm{pH}$ of experimental area was 7.6 with having sandy loam texture. The researcher during investigation considers these two factors have significant changeable role among quantity and quality of the alfalfa crop. This investigation done during the winter season of 2016-17, to evaluate the effect of irrigation intervals on forage production and quality of different alfalfa varieties under semi -arid conditions. From these study the researcher manage three irrigation schedule $(10,20$ and 30 days irrigation interval after planting) on three varieties of alfalfa (Supersonic, Sultana and Lucerne 2002) were used to study its effect on agronomic parameters (plant density, plant height, fresh and dry weights per plant, leaf area, fresh forage and dry matter yields per hectare) and quality parameters (crude protein, crude fiber and total ash content). The research was arranged in a randomized complete block design (RCBD) with split plot arrangement and having 3 replications. Data of the Crop growth, yield and the quality related traits was recorded by applying standard procedure. For statistical analysis of the recorded data, Fisher's ANOVA technique was used and the Treatments mean values were compared at 5\% probability level using the least significant difference (LSD) test. Result of the field experiment revealed that the maximum green forage yield of $26.80 \mathrm{t}$ ha- 1 and protein percentage 21.05 was obtained when crop was irrigated 20 days interval and variety Lucerne 2002 was used. Therefore, irrigation with 20 days interval and using Lucerne 2002 variety proved to be best under agro ecological conditions. The mean value for plant density $\left(\mathrm{m}^{2}\right)$, plant height $(\mathrm{cm})$, fresh weight plant ${ }^{-1}(\mathrm{~g})$, dry weight plant ${ }^{-1}(\mathrm{~g})$, fresh forage yield $\left(\right.$ tha $\left.^{-1}\right)$, and dry mater yield $\left(\right.$ tha $\left.^{-1}\right)$ indicated in the table 2.6 (Nasratullah Ehsas et al , 2018).

Table: 2.6. Mean value for plant density $\left(\mathrm{m}^{2}\right)$, plant height $(\mathrm{cm})$, fresh weight plant ${ }^{-1}(\mathrm{~g})$, dry weight plant ${ }^{-1}(\mathrm{~g})$, fresh forage yield (tha-1), and dry mater yield $\left(\right.$ tha $^{-1}$ ) (Nasratullah Ehsas et al, 2018).

\begin{tabular}{|c|c|c|c|c|c|c|}
\hline $\begin{array}{c}\text { Irrigation } \\
\text { interval } \\
\text { (day) }\end{array}$ & $\begin{array}{c}\text { plant density } \\
\left(\mathbf{m}^{2}\right)\end{array}$ & $\begin{array}{c}\text { plant height } \\
\text { (cm) }\end{array}$ & $\begin{array}{c}\text { fresh weight } \\
\text { plant }^{-1}(\mathrm{~g})\end{array}$ & $\begin{array}{l}\text { dry weight } \\
\text { plant }^{-1}(\mathrm{~g})\end{array}$ & $\begin{array}{l}\text { fresh forage } \\
\text { yield }\left(\text { tha }^{-1}\right)\end{array}$ & $\begin{array}{c}\text { dry mater } \\
\text { yield }\left(\text { tha }^{-1}\right)\end{array}$ \\
\hline 10 & 169.22 & 27.89 & 2.61 & 0.61 & 21.62 & 5 \\
\hline 20 & 245.56 & 30.78 & 3.60 & 0.99 & 25.19 & 5.38 \\
\hline 30 & 211.44 & 29.78 & 2.32 & 0.94 & 23.39 & 4.82 \\
\hline
\end{tabular}

\subsection{Effect of irrigation interval on growth and development of tomato}

During reviewed these investigation I have been point out four irrigation interval treatment and their effect on irrigation interval on growth and development of tomato crop production. The area is characterized by mean annual rainfall which varies about 750 to $1200 \mathrm{~mm}$. the temperature are uniformly high throughout the year with annual average minimum of $30^{0} \mathrm{C}$.During this research investigation the researcher was mainly conducted to determine the performance of two sprinkler heads and use one of them to determine suitable irrigation interval for the optimum growth and yield of tomatoes. That means the researcher used sprinkler irrigation method to determine the effect of irrigation interval on crop productivity. These 4 irrigation intervals 1 day $\mathrm{T}_{1}, 3$ day $\mathrm{T}_{2}, 5$ day $\mathrm{T}_{3}$, and 4 day $\mathrm{T}_{4}$ were used as a treatment. The experiment result indicated that the tomato plants productivity under $\mathrm{T}_{1}$ (1 day irrigation interval) had meaningfully higher stem diameter (2.85), fruit mass (45.00), fruit length (5.5), and flower number (2.781) than those under the other treatment ( 3 day $\mathrm{T}_{2}, 5$ day $\mathrm{T}_{3}$, and 4 day $\mathrm{T}_{4}$ ) . The investigator concludes that Irrigation interval of 1 day $\mathrm{T}_{1}$ lead to the best performance in growth and development of tomato production. In this investigation I have seen that they used sprinkler irrigation with on head as well as I have not seen other factors that affect productivities. Table 2.7 indicate effect of irrigation interval on fruit yield, plant height, stem diameter, fruit length (P.O. Boamah et al, 2010).

Table: 2.7. Effect of irrigation interval on fruit yield, plant height, stem diameter, fruit length (P.O. Boamah et al, 2010).

\begin{tabular}{ccccc}
\hline $\begin{array}{c}\text { Irrigation interval } \\
\text { (day }\end{array}$ & fruit yield (g) & plant height $(\mathbf{c m}$ & Stem diameter(mm) & fruit length (mm) \\
\hline $\mathbf{1}$ & 45.00 & 57.79 & 2.85 & 5.55 \\
$\mathbf{3}$ & 27.20 & 34.43 & 2.69 & 4.20 \\
$\mathbf{5}$ & 25.00 & 55.31 & 2.73 & 4.00 \\
$\mathbf{4}$ & 22.5 & 55.44 & 2.78 & 3.95 \\
\hline
\end{tabular}




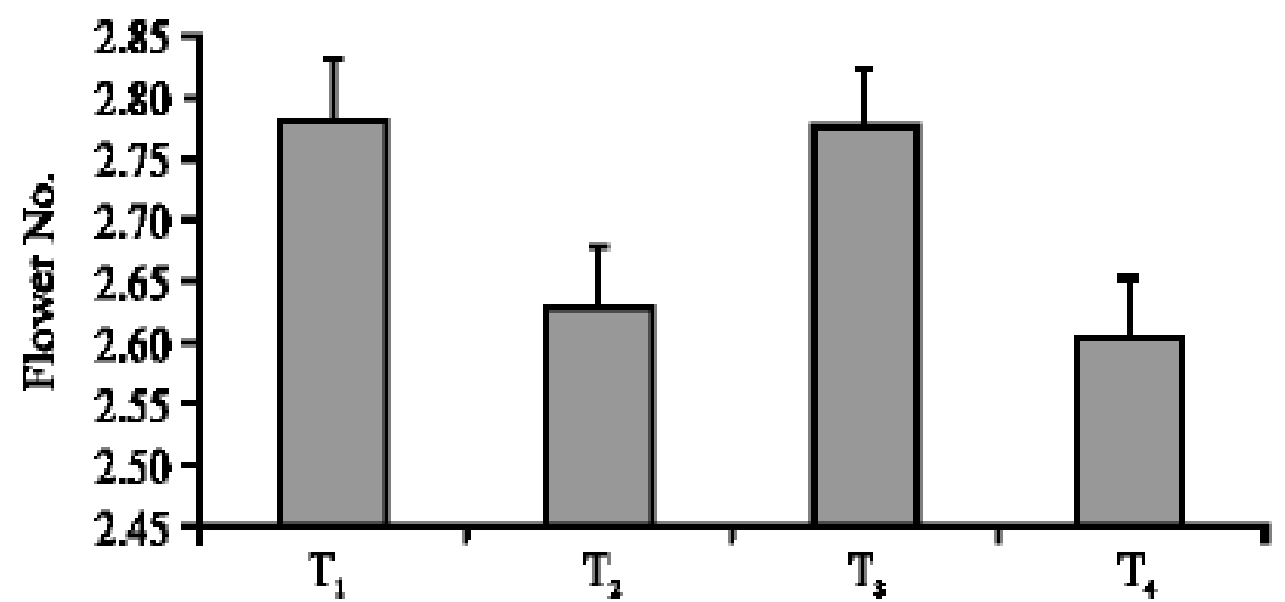

Figure: 2.7. Flower number and irrigation interval (P.O. Boamah et al, 2010).

\subsection{Effect of Irrigation Level and Irrigation Frequency on the Growth of cabbage}

In this study the researcher tries to examine the effect of irrigation level and irrigation frequency on the growth and soil residual NO3-N of the catch crop mini Chinese cabbage (Brassica pekinensis) in a greenhouse. The annual average temperature is $11{ }^{\circ} \mathrm{C}$ with an annual average evaporation of $1500 \mathrm{~mm}$. The cultivated soil layer $(0-80 \mathrm{~cm})$ in the experimental area is heavy soil ( $46 \%$ sand, $43 \%$ silt, and $11 \%$ clay). Based on the investigators idea I have been try to review Nitrogen balance components at harvest in 2014,2015, and 2016, resulting from different irrigation amount, frequency and level WL: 80\% ETc, WM: 120\% ETc, WH:160\%ETc, irrigation interval F2: 2 days, F4: 4 days, F8: 8 days ck: conventional border irrigation with adequate water supply using conventional border irrigation with adequate water supply as a control (CK), three irrigation levels (WH: 160\% crop evapotranspiration (ETc), WM: $120 \%$ ETc and WL: $80 \%$ ETc) and three irrigation frequencies (intervals of F2: 2 days, F4: 4 days, and F8: 8 days) were assessed in 2014, 2015 and 2016 in northwest China. The results showed that the weight of the leaves and leaf stalks was the primary determinant of yield, and that these are the primary $\mathrm{N}$-containing vegetative organs of the plants. At the same irrigation level, the total $\mathrm{N}$ content of the plants increased in the order F8 $<$ F2 $<$ F4. The trend in the total N content in the mini Chinese cabbage plants among different treatments was synchronized with the yield. The highest total $\mathrm{N}$ content in the plants was observed in the WM F4 treatment during all three years. The three-year averages of mini Chinese cabbage above ground biomass, yield and water use efficien cy (WUE) in the WM F4 treatment were 60\%, 64.5\% and $119.2 \%$ higher respectively than in the CK treatment. The residual NO3-N content in the soil in the WM F4 treatment was only $1.3 \%$ higher than that in the CK treatment. The total N uptake in the WM F4 treatment was $79.2 \%$ higher than that in the CK treatment, and the N loss in the WM F4 treatment was $46.3 \%$ lower than that in the CK treatment. Under these experimental conditions, the WM F4 treatment can be recommended as appropriate irrigation regimes for mini Chinese cabbage under fallow greenhouse management in northwest China table 2.8 indicate the total review outputs (Youzhen Xiang et al, 2018).

Table: 2.8. Nitrogen balance components at harvest in 2014, 2015, and 2016, resulting from different irrigation amount, frequency and level WL: $80 \%$ ETc, WM: $120 \%$ ETc, WH: 160\%ETc, irrigation interval F2: 2 days, F4: 4 days, F8: 8 days ck: conventional border irrigation with adequate water supplies (Youzhen Xiang et al, 2018).

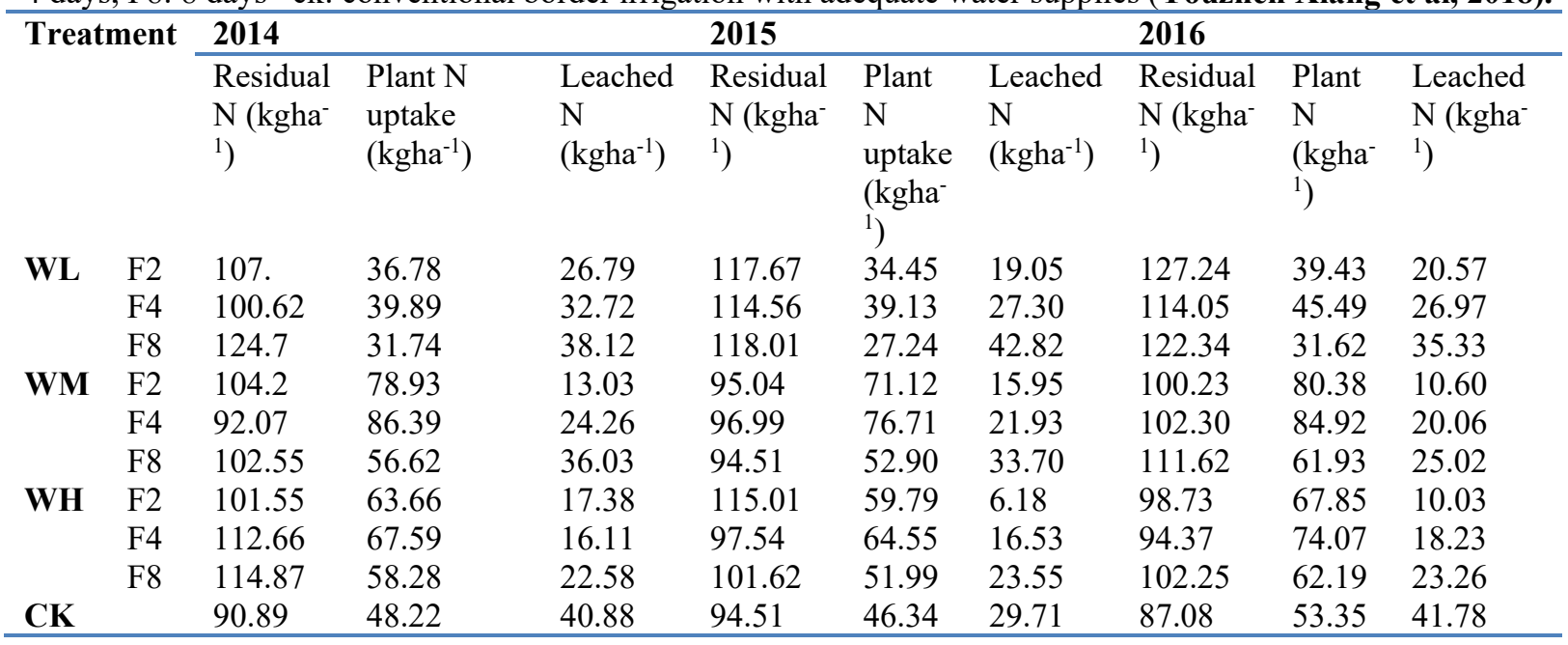




\subsection{Influence of irrigation interval on crop geometry}

In these review I want to see the effect of irrigation interval, geometry and nitrogen level on production of lettuce using drip irrigation method. From this paper the investigator address field experiments were conducted for the period of winter period (October to February) of 2008-09 and 2009-10 to investigate the growth and yield response of lettuce to different irrigation intervals, nitrogen application rates and different crop spacing. Soil analysis revealed that the soil was sandy clay Loam in texture, and its climatic condition were the average monthly maximum and minimum temperature 25.8 and $24.56 \mathrm{C}^{0}, 2008-09$ and 10.84 and10.46 $\mathrm{C}^{0} 2009-10$ respectively. The investigator intended for experimental design 3 crop spacing $45 \mathrm{~cm} \times 30 \mathrm{~cm}(\mathrm{G} 1), 30 \mathrm{~cm} \times 30 \mathrm{~cm}$ $(\mathrm{G} 2)$ and $17.5 \mathrm{~cm} \times 30 \mathrm{~cm}(\mathrm{G} 3)$ (Row $\times$ plant spacing in $\mathrm{cm}), 2$ irrigation interval 2 days $\left(\mathrm{I}_{1}\right)$ and 4 days $\left(\mathrm{I}_{2}\right)$ and 2 levels of nitrogen fertilizer application $60 \mathrm{~kg} \mathrm{ha}^{-1}\left(\mathrm{~N}_{1}\right)$ and $100 \mathrm{~kg}$ ha-1 $\left(\mathrm{N}_{2}\right)$. Three replications were applied for 2 experiments. The coefficient of variation of the dripper discharge used in drip irrigation method was 0.059 and 0.091 in 2008-09 and 2009-10, respectively. The outcomes indicated that lettuce grown with $17.5 \mathrm{~cm} \times 30$ $\mathrm{cm}$ crop geometry, alongside with 2 day irrigation interval and $100 \mathrm{~kg} \mathrm{~N}$ ha-1 fertilizer application scored the maximum plant height $(18.5$ and $17.3 \mathrm{~cm})$, Maximum number of leaves (19 and 16) and head diameter (13.9 and $12.5 \mathrm{~cm}$ ) with $45 \mathrm{~cm} \times 30 \mathrm{~cm}$ crop spacing, along with 2 day irrigation interval and $100 \mathrm{~kg} \mathrm{~N}$ ha-1 fertilizer application rate. The researcher fertilizer concluded from field experimental data that 2 day irrigation interval with $100 \mathrm{~kg} \mathrm{~N}$ ha-1 fertilizer application if joined with closer row spacing may result in higher marketable yield in lettuce crop production as the investigation indicate. The effect of plant morphological characteristics indicated in the table 2.9 as the researcher puts. As I have been review these paper irrigation interval, nitrogen level and plant geometry affect the production of crop as well as the effect of irrigation method drip irrigation and proper management of emitter discharge. (Tejaswini Patil et al, 2012).

Table: 2.9. Growth and yield parameter of lettuce affected by irrigation interval, nitrogen and plant geometry (Tejaswini Patil et al, 2012).

\begin{tabular}{|c|c|c|c|c|c|c|}
\hline \multirow[t]{2}{*}{ Treatment } & \multicolumn{2}{|c|}{ Plant height } & \multicolumn{2}{|c|}{ No of leaves/plant } & \multicolumn{2}{|c|}{ Head diameter } \\
\hline & $2008-09$ & $2009-10$ & $2008-09$ & $2009-10$ & $2008-09$ & $2009-10$ \\
\hline I1 & 16.6 & 15.5 & 15 & 14 & 12.6 & 11.5 \\
\hline $\mathbf{I 2}$ & 15.3 & 14.3 & 14 & 12 & 10.1 & 9.2 \\
\hline CD at $5 \%$ & 0.086 & 0.078 & 0.235 & 0.256 & 0.1124 & 0.1102 \\
\hline N1 & 15.2 & 13.7 & 14 & 12 & 10.8 & 9.0 \\
\hline $\mathbf{N 2}$ & 16.7 & 15.3 & 15 & 13 & 11.9 & 9.9 \\
\hline CD at $5 \%$ & 0.086 & 0.064 & 0.235 & 0.209 & 0.1124 & 0.08995 \\
\hline G1 & 14.9 & 13.5 & 17 & 14 & 12.0 & 9.9 \\
\hline G2 & 16 & 14.5 & 14 & 12 & 11.3 & 9.5 \\
\hline G3 & 16.9 & 15.4 & 12 & 11 & 10.8 & 9.1 \\
\hline CD at $5 \%$ & 0.047 & 0.031 & 0.381 & 0.229 & 0.02737 & 0.00688 \\
\hline $\mathbf{I}_{1} \mathbf{N}_{1} \mathbf{G}_{1}$ & 14.8 & 13.8 & 17 & 15 & 12.7 & 11.4 \\
\hline $\mathbf{I}_{1} \mathbf{N}_{1} \mathbf{G}_{2}$ & 15.9 & 14.8 & 14 & 13 & 12.0 & 10.9 \\
\hline $\mathbf{I}_{1} \mathbf{N}_{1} \mathbf{G}_{3}$ & 16.8 & 15.7 & 12 & 12 & 11.4 & 10.5 \\
\hline $\mathbf{I}_{1} \mathbf{N}_{2} \mathbf{G}_{1}$ & 16.3 & 15.2 & 19 & 16 & 13.9 & 12.5 \\
\hline $\mathbf{I}_{1} \mathbf{N}_{2} \mathbf{G}_{2}$ & 17.5 & 16.3 & 15 & 15 & 13.2 & 12.0 \\
\hline $\mathbf{I}_{1} \mathbf{N}_{\mathbf{2}} \mathbf{G}_{3}$ & 18.5 & 17.3 & 14 & 13 & 12.6 & 11.6 \\
\hline $\mathbf{I}_{2} \mathbf{N}_{1} \mathbf{G}_{1}$ & 13.6 & 12.7 & 15 & 13 & 10.1 & 9.1 \\
\hline $\mathbf{I}_{2} \mathbf{N}_{1} \mathbf{G}_{2}$ & 14.6 & 13.7 & 13 & 11 & 9.6 & 8.7 \\
\hline $\mathbf{I}_{2} \mathbf{N}_{1} \mathbf{G}_{3}$ & 15.4 & 14.4 & 11 & 10 & 9.2 & 8.4 \\
\hline $\mathbf{I}_{2} \mathbf{N}_{2} \mathbf{G}_{1}$ & 15.0 & 14.0 & 17 & 15 & 11.1 & 10.0 \\
\hline $\mathbf{I}_{2} \mathbf{N}_{2} \mathbf{G}_{2}$ & 16.1 & 15.0 & 14 & 12 & 10.5 & 9.6 \\
\hline $\mathbf{I}_{2} \mathbf{N}_{2} \mathbf{G}_{3}$ & 17.0 & 15.9 & 12 & 11 & 10.1 & 9.3 \\
\hline CD at $5 \%$ & 0.095 & 0.075 & 0.762 & 0.561 & 0.05474 & 0.01685 \\
\hline
\end{tabular}

$\mathrm{I}_{1}=$ one day irrigation interval, $\quad \mathrm{N}_{1}=60 \mathrm{~kg} /$ ha nitrogen application

$\mathrm{I}^{2}=$ two day irrigation interval, $\quad \mathrm{N}_{2}=100 \mathrm{~kg} /$ ha nitrogen application

$\mathrm{G}_{1}=45 \mathrm{~cm} * 30 \mathrm{~cm}$ plant geometry, $\mathrm{G}_{2}=30 \mathrm{~cm} * 30 \mathrm{~cm}, \mathrm{G}_{3}=17.5 \mathrm{~cm} * 30 \mathrm{~cm}$

\section{CONCLUSION}

In general in these review I have been review the effect of irrigation intervals on growth and yield of onion, effect of irrigation intervals to optimize maize yield, effect of irrigation interval on growth characteristics for Chile pepper, effect of irrigation interval on vegetative growth and yield, effects of irrigation interval on growth analysis of soybean, effect of irrigation intervals on forage production, effect of irrigation interval on growth and development of tomato, effect of irrigation level and irrigation frequency on the growth of mini Chinese cabbage and Influence of irrigation interval, nitrogen level and crop geometry on production lettuce. The review covers 
the type of crops that include cereal, fruit, vegetable and forage $b / c$ type of the crop is one of the determinant factors for irrigation interval. On the other hand the chemical composition of the soil and water and fertilizer application is some of factors that determine the irrigation interval. As the table 3.1 indicates the best performance irrigation interval for maize, pepper, okra, soybean, forage, tomato, cabbage and lettuce are $5,6,1$, $12,8,20,1,4$ and 2 day respectively. The main reason for this different irrigation interval is the temperature variation from place to place, method of irrigation, soil type, crop type, and other factors such as fertilizer application, design of treatment, plant geometry, chemical compositions of the soil and water. From the table 3.1 the maximum temperature $70{ }^{\circ} \mathrm{C}$ AND $30{ }^{\circ} \mathrm{C}$ best performance of irrigation interval is 1 day and in the forage crop the best performance of irrigation interval is 20 day.

Table 3.1 factors determine irrigation interval for crop productivity

\begin{tabular}{|l|l|l|l|l|l|l|}
\hline Crop & Type & $\begin{array}{l}\text { Soil } \\
\text { type }\end{array}$ & $\begin{array}{l}\text { Method of } \\
\text { irrigation }\end{array}$ & Temperature & $\begin{array}{l}\text { Tested irrigation } \\
\text { interval day }\end{array}$ & $\begin{array}{l}\text { Best irrigation } \\
\text { interval day }\end{array}$ \\
\hline Onion & Vegetable & SL & nursery & & $5,10,15,20$ & 5 \\
\hline Maize & Cereal & SL & Drip & $18.8^{\circ} \mathrm{C}$ & $3,6,9,12,15$ & 6 \\
\hline pepper & Fruit & SCL & container & $70^{\circ} \mathrm{C}(\mathrm{GH})$ & $1,3,4,5$ & 1 \\
\hline Okra & vegetable & & Furrow & & $12,18,24$ & 12 \\
\hline soybean & Cereal & & Furrow & $15^{\circ} \mathrm{C}$ & $3,8,13$ & 8 \\
\hline Forage & grass & SL & Furrow & $17.4^{\circ} \mathrm{C}$ & $10,20,30$ & 20 \\
\hline Tomato & Fruit & & sprinkler & $30^{\circ} \mathrm{C}$ & $1,3,5,4$ & 1 \\
\hline Cabbage & Vegetable & SL & Border & $11^{\circ} \mathrm{C}$ & $2,4,8$ & 4 \\
\hline Lettuce & Vegetable & SCL & drip & $17.5^{\circ} \mathrm{C}$ & 2,4 & 2 \\
\hline
\end{tabular}

$\mathrm{SL}=$ Sandy Loam, $\mathrm{SCL}=$ Sandy Clay Loam, $\mathrm{GH}=$ Green House Temperature

\section{RECOMMENDATION}

For the determination of best productive and water saving interval of irrigation all major factors of that determine irrigation scheduling are properly addressed for example crop type, crop growth stage soil type, climate condition (temperature, rainfall, humidity, sunshine hour and wend speed) duration of the environment should be properly addressed and potential evapotranspiration and reference evapotranspiration should be estimated for determine of irrigating interval. In in these case some of the studies are properly addressed these important parameters but some of the study not indicates. On the other hand chemical composition of water and soil, fertilizer application, method of research design and plant geometry are should be identify to eradicate the misjudgment of your best productivity of irrigation interval.

\section{REFERENCE}

De Fraiture, C., \& Wichelns, D. (2010). Satisfying future water demands for agriculture. Agricicultural Water Management, 97(4), 502-511.

De Fraiture, C., Molden, D., \& Wichelns, D. (2010). Investing in water for food, ecosystems, and livelihoods: An overview of the comprehensive assessment of water management in agriculture. Agricicultural Water Management, 97(4), 495-501.

Guoqiang Zhang, Dongping Shen, Bo Ming, Ruizhi Xie, Xiuliang Jin,Chaowei Liu , Peng Hou, Jun Xue, Jianglu Chen, Wanxu Zhang, Wanmao Liu,Keru Wang, Shaokun Li . ( 2019 ).Using irrigation intervals to optimize water-use efficiency and maize yield in Xinjiang, northwest China. THE CROPJOURNAL $7322-334$

Haile g/mariamtesfu, (2014). Adoption of modern agricultural technologies in urban agriculture a case study in mekelle city-vegetable growers. Mekelle university college of business and economics department of management.

Hassan A.Hussein, Aimen K. Metwally, Kotb A. Farghaly and Mahroos. A. Bahawirth. (2011). Effect of Irrigation Interval (Water Stress) on Vegetative Growth and Yield in Two Genotypes of Okra. Australian Journal of Basic and Applied Sciences, 5(12): 3024-3032.

Lake Mekonnen. (2018). Effects of Irrigation Interval on Growth Analysis of Soybean Journal of Natural Sciences Research, Vol.8, No.7.

Mateen ul Hassan Khan, Muhammad Imran and Tahir Hussain Chattha. (2005). Effect of Irrigation Intervals on Growth and Yieldof Onion Varieties Swat-1 and Phulkara. Journal of Applied Sciences Research 1(2): $112-116$.

Nasratullah Ehsas, Muhammad Asif Iqba, Saleh Muhammad Ahmadi. (2018). Effect of Irrigation Intervals on forage production and quality of different alfalfa varieties under semi-arid conditions. International Journal of Environment, Agriculture and Biotechnology.

P.O. Boamah, L.K. Sam-Amoah and J.D. Owusu-sckyere. (2010). Effect of irrigation interval on growth and 
development of tomato under spreinkler. Asian journal of agricultural research 4(4) 196-203.

Saleh M. Ismaill and Kiyoshi Ozawa. (2009).Effect Of Irrigation Interval on Growth Characteristics, Plant Water Stress Tolerance Andwater Use Efficiency For Chile Pepper. International Water Technology Conference, IWTC, Hurghada, Egypt.

Tejaswini Patil, Man Singh*, Balraj Singh**, Manoj Khanna, D.K. Singh and S.S. Parihar,.( 2012). Influence of irrigation interval, nitrogen level and crop geometry on production of trickle irrigated lettuce. Water Technology Centre, Indian Agricultural Research Institute, Indian J. Hort. 69(3): 360-368

Youzhen Xiang, Haiyang Zou, Fucang Zhang, *, Shengcai Qiang, You Wu, Shicheng Yan , Haidong Wang, Lifeng Wu , Junliang Fan and Xiukang Wang (2018). Effect of Irrigation Level and Irrigation Frequency on the Growth of Mini Chinese cabbage and ResidualSoil Nitrate Nitrogen. 